\title{
The Impact of Financing Pattern on Firm Growth: Evidence from Swedish Micro Firms
}

\author{
Darush Yazdanfar \\ Correspondence: Darush Yazdanfar, Assistant Professor, Department of Social Sciences, Mid Sweden \\ University, Regementsgatan 25-27, Östersund 831 25, Sweden. Tel: 46-73-989-2800. E-mail: \\ darush.yazdanfar@miun.se
}

Received: May 23, $2012 \quad$ Accepted: June 8, $2012 \quad$ Online Published: July 31, 2012

doi:10.5539/ibr.v5n9p16 URL: http://dx.doi.org/10.5539/ibr.v5n9p16

\begin{abstract}
This study examines the impact of financial structures on the growth of micro firms in Sweden. The objective of this paper is to explore whether firms' growth can be associated with patterns of financial acquisition and whether these patterns influence firms' growth differently when the source is either internal or external. Based on agency cost theory, hypotheses were formulated and tested with panel data consisting of 12101 micro firms, using 84707 observations for the period 2006-2007. The data were analysed using the seemingly unrelated regression (SUR) model. The empirical results reveal that internal financial sources - retained profit significantly influence firm growth. Similarly, short-term debt and growth are positively related. However, firm growth is generally more sensitive to retained profit than short-term debt. Interestingly, long-term debt generally has no effect on growth. The findings also indicate that size, age, and industry affiliation influence firm growth. Finally, agency cost theory is relevant in explaining the relationship between financing pattern and growth.
\end{abstract}

Keywords: growth determinants, financing pattern, small business financing, SUR model, Swedish micro firms

\section{Introduction}

Firm growth and, in particular, small firm growth has become one of the most important themes in business literature. Several arguments have been made to explain the significance of growth due to its role as a precondition for firm survival, innovation and technological change (Aghion, Fally \& Scarpetta, 2007; Pagano \& Schivardi, 2003). An increase in firm growth might increase demand from it towards other sectors, which could enhance economic activity and as a result lead to growth at the macro level. The generation of employment and employment dynamics, as well as contribution to productivity and economic growth, are other factors that have attracted considerable attention to small firm growth and made it an interesting field of study (North \& Smallbone, 1995; Wiklund, 1998). However, small firms face financial constraints and difficulties in acquiring financial sources due to market imperfection, moral hazard, informational asymmetries, and the agency problem (Myers, 1977; Myers \& Majluf, 1984). There is a relatively large body of literature on growth determinants and barriers to growth, but the impact of internal and external financial sources on firm growth has remained unexplored.

This study empirically explores the relationship between capital structure and growth. It also examines whether agency cost theory can explain the capital structure of Swedish micro firms. The findings offer insight into the dominant financing behaviour of micro firms in Sweden.

The paper is organized as follows: Section 2 presents the key conceptual framework and summarizes previous empirical studies. Section 3 gives an overview of the literature used to derive variables, their theoretical justification, the research method, research sampling, data collection strategy and data analysis techniques. The results are presented in section 4 , and the final section draws together the main conclusions.

\section{Theoretical Framework and Previous Empirical Studies}

\subsection{Theoretical Framework}

From the perspective of agency cost theory, firms with growth opportunities have a smaller debt ratio and rely mainly on internal resources such as retained profit and equity capital (Myers, 1977). The explanation is that owners/managers strive to maximize their welfare and at the same time to be less dependent on creditors. To prevent agency problems between firms and their external financiers and to avoid under-investment or financing 
shortage, firms use short-term debt (Childs, Mauer \& Ott, 2005; Myers, 1977). Owners/managers of small businesses who aspire to keep their independence use their own financial resources more efficiently (Hutchinson, 1995; Shrivastava \& Grant, 1985). The lower the debt financing, the less moral hazard behaviour there is and the higher the growth prospects will be. Thus, agency cost theory predicts a negative relationship between long-term leverage and growth (Jensen \& Meckling, 1976; Stulz, 1990; Titman \& Wessels, 1988). On the other hand, the relationship between equity capital, short-term leverage, and growth are considered to be positive (Myers, 1977). In other words, the financial sources and patterns firms exploit have an impact on the growth of the firm and play fundamentally different roles in this process (McConnell \& Servaes, 1995).

\subsection{Previous Empirical Studies}

Given the significance of firm growth, a good number of empirical studies in the last few decades have focused on the financial barriers to growth as well as the relationship between growth and different sources of financing; however, the results of these studies are mixed and complicated. This might be because of the multiple and complex variables and different approaches which have been deployed to explain the relationship between growth and financial resources.

Cassar and Holmes (2003) and Hall, Hutchinson and Michaelas (2004) find positive associations between growth and both long-term and short-term debt ratios, while others present mixed evidence from this relationship (Chittenden, Hall \& Hutchinson, 1996; Esperança, Gama \& Gulamhussen, 2003; Jordan, Low \& Taylor, 1998). Some researchers emphasize the positive relationships between sales growth and leverage (see Barton, Ned \& Sundaram, 1989; Kester, 1986; Titman \& Wessels, 1988). Other evidence suggests that higher growth firms use less debt (see Barclay, Smith \& Watts, 1995; Kim \& Sorensen, 1986; Rajan \& Zingales, 1995; Roden \& Lewellen, 1995; Stulz, 1990), while Michaelas, Chittenden \& Poutziouris (1999) argue that future growth is positively related to leverage and long-term debt.

\section{Selection of Variables, the Research Hypotheses, Sample and Model Specification}

\subsection{Selection of Variables}

The variables selected for the study of the impact of financing pattern on growth might overlap other variables such as age, size, and industry affiliation. In order to identify the impact of each variable in this study, the explanatory variables were classified in two groups. The first group comprised the control variables: age, size, and industry (a dummy variable). The second group comprised three variables related to the firm's financial sources: equity, short-term and long-term debt. These independent variables measured the availability of various kinds of financial sources.

\subsection{The Dependent Variable}

The dependent variable in this study, growth, can be defined in a different ways. Based on most previous studies, growth is defined here as the change in sales (Beck, Demirgüc-Kunt \& Maksimovic, 2005; Hart, 2000).

\subsection{The Independent Variables}

\subsubsection{Age}

The age of a firm has been regarded as one of the most important explanatory variables of growth (Autio, 2005; Evans, 1987; Storey, 1994) and has been widely used to explain it (Becchetti \& Trovato, 2002; Evans, 1987). However, the relationship between firm age and growth is not monotonic and is complex (Jovanovic, 1982). The disagreements about the relationship between age and the growth of firms in the extant literature can be explained partly by the multi-dimensionality and complexity of the phenomenon of growth, especially in small firms. For instance, some previous empirical studies suggest a positive effect of firm age on growth (Das, 1995; Elston, 1993), while others have shown a negative relation between the variables (Almeida \& Campello, 2007; Becchetti \& Trovato, 2002; Hobdari, Derek \& Mygind, 2009). Given the resource-based hypothesis, as firms get older, theoretically, it is likely that their access to financial resources will improve. Thus a positive relationship between age and growth is expected in the present study.

\subsubsection{Size}

In previous studies, firm size has been found to play a significant role in the pattern of growth and finance (Beck et al., 2005; Evans, 1987; Storey, 1994). However, there is no agreement among previous studies indicating whether firm size has a general relationship with growth (Evans, 1987; Storey, 1994; Variyam \& Kraybill, 1992; Wiklund, 1998). Given its impact on firm growth, therefore, it is interesting to consider firm size as a control variable. 
Some previous studies suggest that smaller firms are likely to be financially constrained - with a consequently negative impact on firm growth (Audretsch \& Elston, 2002, 2006; Oliveira \& Fortunato, 2006). Accordingly, there would be a positive relationship between size and growth (Katsikeas \& Piercy, 1993; Philp, 1998; Wiklund, 1998). Conversely, other researchers observe that smaller, new-born firms grow faster than larger, older firms (Almeida \& Campello, 2007; Katsikeas \& Piercy, 1993; Philp, 1998; Wiklund, 1998). However, Evans (1987) finds that firm size is an important factor influencing performance. Firm size is strongly correlated with age and therefore it is not surprising that negative effects of age on growth have been reported (e.g., Evans, 1987; Yasuda, 2005).

\subsubsection{Industry Affiliation}

It is pointed out in the literature that firm growth is determined not only by the firm's access to financial resources or its specific characteristics, but also by industry affiliation (Delmar, 1997; Delmar, Davidsson \& Gartner, 2003; Gilbert, McDougall \& Audretsch, 2006). Due to the connections between firms in a particular industry, the growth of that sector is likely to have a pulling effect on member firms (Gilbert et al., 2006). The development stage of the industry is another variable having a strong impact on firm growth (Gilbert et al., 2006). The network position of firms may also influence their growth. Accordingly, to control for specific industrial characteristics, sector dummies identifying sectors at a one-digit level are used in this study.

\subsection{Financial Structure Variables}

It has been argued that credit constraints, lack of external debt, and equity capital are the main obstacles to the growth of small and medium-sized enterprises (Becchetti \& Trovato, 2002). Financial assets can quite easily be transformed into other types of resources. With access to sufficient financial assets, firms are able to develop their growth capacity in different ways, for example, by using new technology, acquiring expertise and entering new markets (Castrogiovianni, 1996). Therefore, many empirical studies have regarded a lack of financial resources as an important barrier to growth (Audretsch \& Elston, 2002; Becchetti \& Trovato, 2002; Müller \& Zimmermann, 2008; Oliveira \& Fortunato, 2006; Reid, 2003; Storey, 1994).

Information asymmetry, moral hazard and agency costs are the factors that prevent small, young firms from relying on bank financing; these firms, therefore, mainly deploy other alternatives, such as original equity investment or retained profit, to fund their business. It is expected that firm growth is positively related to the proportion of internal financial resources in terms of the retained profit used to finance a firm's assets. If firm's risk under-investment and their internal financial resources are insufficient, it would be reasonable for them to turn to short-term debt as a second financial alternative, such as short-term loans or trade credits, before choosing long-term loans as a financial source (Hall et al., 2004; Titman \& Wessels, 1988). Using short-term debt considerably decreases the agency costs of under-investment and, at the same time, enables the owners/managers to retain control of the firm. Consequently, it is expected that growth is, in general, positively related to short-term ratio. Finally, as discussed, firms with growth opportunities will have a smaller proportion of long-term debt in their financing pattern because growth opportunities can create moral hazard situations and increase agency costs; however, in these cases the owners/managers of a small firm normally have an incentive to take risks in order to grow. However, the results of this growth, if realized, will not be shared by lenders, leading to agency conflict. This will be reflected in increased costs from long-term debt, which means high growth firms will require less long-term debt. Therefore, growth is expected to have a negative relationship with long-term debt.

Retained profit is defined as post-tax profit and dividend earnings. The loan-to-deposit (LTD) ratio is defined as debt repayable beyond one year, as a percentage of total assets. The short-term debt (STD) ratio is defined as debt repayable within one year, as a percentage of total assets.

\subsection{The Research Hypotheses}

Based on the agency theory of capital structure and previous findings, the hypotheses are formulated as follows:

H1: Age is positively related to growth.

$\mathrm{H} 2$ : Size is positively related to growth.

H3: Industry affiliation is significantly related to growth.

H4: Increased use of retained profit is positively related to growth.

H5: Increased use of short-term debt is positively related to growth.

H6: Increased use of long-term debt is negatively related to growth. 


\subsection{Sample}

Data for this study were originally drawn from Statistics Sweden (SCB - Statistiska centralbyrån), including standardized and detailed balance sheet and income statement data, as well as variables of a qualitative nature from all Swedish limited liability firms. The initial sample consisted of all independent and unlisted active micro firms in six industry sectors, totalling 135257 firms in the period 2006-2007. The sample covers the micro firms, which are defined according to Statistics Sweden as firms with fewer than ten employees.

Since the theoretical framework of this study draws on agency cost theory, this paper focuses on micro firms, which face greater information asymmetry and moral hazard than larger firms and are, therefore, extremely affected by agency costs. To avoid sampling bias, the following were omitted from the sample: firms without employees, firms with negative equity or debt, outliers, missing observations, firms with operating revenues less than SEK 120000 and firms with total assets less than SEK 100000 annually. The final sample consisted of a comprehensive panel of 12101 firms in the period 2006-2007, comprising a total of 84707 observations.

\subsection{Model Specification}

To identify the impact of funding sources and control variables on firm growth, the seemingly unrelated regression (SUR) model was employed in this research. The explanatory variables were broadly categorized into (1) basic characteristics of the firm: size and age, (2) the industry sector to which the firms belong and which are beyond the control of the firms' owners/managers, and (iii) financial variables that are under the direct control of owner/managers and which affect the ability of the firms to deal with external obstacles such as financial constraints.

The basic SUR has the following form:

For the complete sample

$$
\text { Growth }_{i, t}=\alpha_{t}+\beta_{1} \text { Age }_{i, t}+\beta_{2} \text { Size }_{i, t}+\beta_{3} C R F_{i, t}+\beta_{4} \operatorname{CSTD}_{i, t}+\beta_{5} \operatorname{CLTD}_{i, t}+\beta_{6} \text { Indus }_{i, t}+\mu_{i t}
$$

For the sample of each industry sector

$$
\text { Growth }_{i, t}=\alpha_{t}+\beta_{1} \text { Age }_{i, t}+\beta_{2} \text { Size }_{i, t}+\beta_{3} \operatorname{CRF}_{i, t}+\beta_{4} \operatorname{CSTD}_{i, t}+\beta_{5} \operatorname{CLTD}_{i, t}+\mu_{i t}
$$

Where

$\alpha_{\mathrm{t}}=$ constant

Growth $_{i, t}=$ firm growth; the percentage change of sale (Growth $=$ Qs1 - Qs0 x 100)

$\beta_{1} \mathrm{Age}_{i, t}=$ age of firm $i$ at time $t$; age is the natural logarithm of number of years since firm inception as of the year of data collection

$\beta_{2}$ Size $_{i, t}=$ size of firm $i$ at time $t$; firm size (SIZE) is measured as the natural logarithm of the firm's book value of sale

$\beta_{3} C R F_{i, t}=$ change in firm's retained profit in terms of percentage in periods $t$ and $t-1$

$\beta_{4} C S T D_{i, t}=$ change in firm's short-term debt in terms of percentage in periods $t$ and $t-1$

$\beta_{5} C L T D_{i, t}=$ change in firm's long-term debt in terms of percentage in periods $t$ and $t-1$

$\beta_{6}$ Indus $_{i, t}=$ categorical variable; industry

$\mu=$ error term

\section{Results of Empirical Analysis}

\subsection{Results of Descriptive Analysis}

Table 1 reports descriptive statistics for dependent and independent variables. On average, the firms in the sample employ 3.35 people and have been operating for 18.19 years. On average, firm growth tends to rise by $2.5 \%$ annually. The construction sector accounts for the highest and the consulting sector for the lowest growth. On average, firms are mostly financed by equity capital. The second important financial source in the firms' total assets is short-term debt. Long-term debt plays no important role in the financial structures of the firms. Thus, it seems that firms tend to have a higher ratio of internal resources in term of equity, retained profit, and cash flow. Finally, the Jarque-Bera (J-B) tests indicate that the observations are normally distributed. Applying the single-digit Standard Industrial Classification (SIC), the sample consists of firms in seven industry sectors: retail trade $(36.1 \%$ of the sample), consulting $(19.1 \%)$, metal manufacturing $(9.3 \%)$, restaurants $(7.8 \%)$, construction $(8.4 \%)$, agriculture $(5.1 \%)$, and health (14.2\%). Metal manufacturing, construction and agriculture correspond to 
around $30.6 \%$ of the sample, while services (e.g., retail trade, consulting, restaurants, and health sectors) are highly represented $(69.4 \%)$.

Table 1. Summary of descriptive statistics of the dependent and independent variables

\begin{tabular}{|c|c|c|c|c|c|c|c|c|c|}
\hline & Retail Trade & Consulting & Metal & Restaurant & Construction & Agriculture & Health & Total & J-B $p$-value \\
\hline No of firms & 4369 & 2316 & 1128 & 944 & 1011 & 615 & 1718 & 12101 & 0.00 \\
\hline Firms (Per cent) & 36.1 & 19.1 & 9.3 & 7.8 & 8.4 & 5.1 & 14.2 & 100 & 0.00 \\
\hline Growth (Mean) & 2.63 & 2.29 & 2.65 & 2.49 & 2.69 & 2.67 & 2.39 & 2.53 & 0.00 \\
\hline Growth (Std.dev) & 0.66 & 0.61 & 0.63 & 0.58 & 0.71 & 0.61 & 0.63 & 0.66 & 0.00 \\
\hline Age (Mean) & 19.7 & 16.18 & 20.19 & 1.03 & 17.05 & 19.8 & 18.47 & 18.19 & 0.00 \\
\hline Age (Std.dev) & 14.37 & 10.72 & 11.5 & 0.3 & 11.71 & 10.82 & 10.13 & 12.36 & 0.00 \\
\hline Employees (Mean) & 3.73 & 2.21 & 4.08 & 4.44 & 3 & 2.66 & 3.31 & 3.35 & 0.00 \\
\hline Employees (Std.dev) & 2.29 & 1.68 & 2.5 & 2.26 & 2.15 & 1.82 & 2.28 & 2.28 & 0.00 \\
\hline STD (Mean) & 0.38 & 0.37 & 0.33 & 0.42 & 0.4 & 0.23 & 0.27 & 0.35 & 0.00 \\
\hline STD (Std.dev) & 0.16 & 0.17 & 0.14 & 0.17 & 0.17 & 0.21 & 0.13 & 0.17 & 0.00 \\
\hline LTD (Mean) & 0.07 & 0.04 & 0.08 & 0.06 & 0.07 & 0.07 & 0.14 & 0.07 & 0.00 \\
\hline LTD (Std.dev) & 0.11 & 0.09 & 0.12 & 0.12 & 0.12 & 0.15 & 0.13 & 0.12 & 0.00 \\
\hline EQ (Mean) & 0.55 & 0.59 & 0.59 & 0.52 & 0.53 & 0.7 & 0.59 & 0.58 & 0.00 \\
\hline EQ (Std.dev) & 0.37 & 0.34 & 0.15 & 0.41 & 0.18 & 0.12 & 0.11 & 0.31 & 0.00 \\
\hline CRF (Mean) & 0.14 & 0.19 & 0.21 & 0.17 & 0.19 & 0.14 & 0.13 & 0.21 & 0.00 \\
\hline CRF (Std.dev) & 0.37 & 0.34 & 0.15 & 0.41 & 0.18 & 0.12 & 0.11 & 0.31 & 0.00 \\
\hline CSTD (Mean) & 0.09 & 0.31 & 0.31 & 0.35 & 0.31 & 0.02 & 0.12 & 0.25 & 0.00 \\
\hline CSTD (Std.dev) & 0.81 & 1.24 & 1.59 & 0.25 & 1.24 & 0.63 & 0.59 & 0.21 & 0.00 \\
\hline CLTD (Mean) & 0.17 & 0.16 & 0.16 & 0.11 & 0.16 & 0.34 & 0.25 & 0.2 & 0.00 \\
\hline CLTD (Std.dev) & 0.11 & 0.12 & 0.14 & 0.15 & 0.16 & 0.32 & 0.17 & 0.33 & 0.00 \\
\hline
\end{tabular}

Note: J-B $p$-values are reported for the Jarque-Bera normality test: $\mathrm{H} 0=$ normality.

Comparison of growth between the sectors shows that the construction, metal and agriculture sectors appear to have a growth higher than average $(2.53 \%)$.

\subsection{Results of Correlation Analysis}

The results of the correlation analysis of dependent and independent variables are reported in Table 2 and are used to examine the potential risk of collinearity among variables and to control the relationship between variables.

Table 2. Results of correlation analysis

\begin{tabular}{llllllll}
\hline & Grwoth & Agelog & Size & CRF & CSTD & CLTD & Indus \\
\hline Growth & 1 & $-0.11^{* *}$ & $0.051^{* *}$ & $0.08^{* *}$ & $0.04^{* *}$ & $0.03^{* *}$ & $0.06^{* *}$ \\
& & 0.000 & 0.000 & 0.000 & 0.000 & 0.000 & 0.000 \\
Age & $-0.11^{* *}$ & 1 & 0.0821 & -0.095 & 0.0007 & -0.014 & 0.1556 \\
& 0.000 & 0.000 & 0.000 & 0.000 & 0.94 & 0.13 & 0.000 \\
Size & $0.051^{* *}$ & $0.082^{* *}$ & 1 & -0.093 & -0.154 & 0.0294 & 0.0884 \\
& 0.000 & 0.000 & 0.000 & 0.000 & 0.000 & 0.000 & 0.000 \\
CRF & $0.08^{* *}$ & $-0.09^{* *}$ & $-0.08^{* *}$ & 1 & 0.065 & -0.008 & 0.0101 \\
& 0.000 & 0.000 & 0.000 & 0.000 & 0.000 & 0.35 & 0.27 \\
CSTD & $0.04^{* *}$ & 0 & $-0.15^{* *}$ & $0.06^{* *}$ & 1 & 0.0401 & 0.0138 \\
& 0.000 & 0.94 & 0.000 & 0.000 & 0.000 & 0.000 & 0.13 \\
CLTD & $0.03^{* *}$ & -0.013 & $0.029^{* *}$ & -0.008 & $0.041^{* *}$ & 1 & $-0.01^{*}$ \\
& 0.000 & 0.13 & 0.000 & 0.351 & 0.000 & & 0.04 \\
Indus & $0.06^{* *}$ & $0.15^{* *}$ & $0.08^{* *}$ & 0.01 & 0.011 & $-0.01^{*}$ & 1 \\
& 0.000 & 0.000 & 0.000 & 0.27 & 0.13 & 0.041 & 0.000 \\
$\mathrm{~N}$ & 12101 & 12101 & 12101 & 12101 & 12101 & 12101 & 12101 \\
\hline J-B $p$-value & 0.00 & 0.00 & 0.00 & 0.00 & 0.00 & 0.00 & 0.00 \\
\hline
\end{tabular}

Note: ${ }^{* *}$ Correlation is significant at the 0.01 level (2-tailed). ${ }^{*}$ Correlation is significant at the 0.05 level (2-tailed). J-B $p$-values are reported for the Jarque-Bera normality test: $\mathrm{H} 0=$ normality. 
As the results show, the correlation coefficients are not large enough to cause collinearity problems in the regressions but are statistically significant at the usual levels of significance. A significant relationship between firm growth and a set of independent variables consisting of age, size, financing sources, and industry categorization is observed. This implies that achieving a higher level of growth is associated with larger size and higher access to capital sources. However, the relationship between retained profit and growth is stronger than CSTD and CLTD. As firm age and size increases, the proportion of retained profit decreases. As shown in Table 2 , firm growth is significantly positively correlated with size, retained profit, CSTD, CLTD, and industry. On the other hand, the relationship between firm growth and age is significantly negative, demonstrating that younger firms grow faster. Long-term debt has inverse but non-significant associations with retained profit, which indicates a complementary effect between them. The results of the J-B tests confirm that the variables are normally distributed, emphasizing the strong validity of the results.

The young, small firms that are undercapitalized encounter greater barriers when attempting to access finance, in particular long-term bank debt. These firms also suffer from information problems when seeking to finance their investments.

\subsection{Results of SUR Models}

\subsubsection{Complete SUR Model}

The complete SUR model includes firms in all industry sectors and focuses on the impact of age, size, change in retained profit, change in short- and long-term debt and industry affiliation on growth. The results of this model show that five out of the six variables are significant in explaining the change in the dependent variable. The explanatory powers of each independent variable are represented by the beta coefficients. Consistent with Hypotheses 2, 3, and 4, the coefficients of size, change in retained profit, change in short-term debt, and industry affiliation are positive and significant at the $1 \%$ level. Contradictory to Hypothesis 1 , the estimated coefficient of age is negative and statistically significant at the $1 \%$ level. This implies that age has a negative effect on growth. Thus, in general, large young firms with increasing retained profit appear to have larger growth compared with other firms. It indicates that the larger the firms are, the more they exploit scale economies compared with smaller firms. Beta values show that retained profit is the variable among the financing pattern variables that has the largest influence on growth, with a beta value of $0.231(p=.000)$. Moreover, change in long-term debt shows a non-significant relation with growth, which can be explained by the fact that the average long-term leverage of the sample is very low.

Table 3. Summary of SUR Model of Relation between Explanatory Variables and Growth, by Industry Sector

\begin{tabular}{|c|c|c|c|c|c|c|c|c|}
\hline Coef & Retail Trade & Consulting & Metal & Restaurant & Construction & Agriculture & Health & Total sample \\
\hline \multirow[t]{2}{*}{ Age } & -0.559 & -0.175 & -0.173 & -0.316 & -0.318 & -0.329 & -0.062 & -0.245 \\
\hline & 0.000 & 0.000 & 0.000 & 0.000 & 0.000 & 0.000 & 0.000 & 0.000 \\
\hline \multirow[t]{2}{*}{ Size } & 0.839 & 0.404 & 0.721 & 0.516 & 0.813 & 0.104 & 0.933 & 0.720 \\
\hline & 0.000 & 0.000 & 0.000 & 0.000 & 0.000 & 0.000 & 0.000 & 0.000 \\
\hline \multirow[t]{2}{*}{$\mathrm{CRF}$} & 0.068 & 0.003 & 0.943 & 0.001 & 0.007 & 0.004 & 0.009 & 0.232 \\
\hline & 0.000 & 0.000 & 0.000 & 0.000 & 0.000 & 0.002 & 0.000 & 0.000 \\
\hline \multirow[t]{2}{*}{ CSTD } & 0.015 & 0.019 & 0.096 & 0.437 & 0.143 & 0.015 & 0.148 & 0.036 \\
\hline & 0.001 & 0.001 & 0.000 & 0.000 & 0.000 & 0.618 & 0.000 & 0.000 \\
\hline \multirow[t]{2}{*}{ CLTD } & 0.000 & 0.000 & 0.000 & 0.000 & 0.001 & 0.000 & 0.000 & 0.000 \\
\hline & 0.483 & 0.023 & 0.563 & 0.885 & 0.373 & 0.098 & 0.533 & 0.034 \\
\hline \multirow[t]{2}{*}{ Indus } & -- & -- & -- & -- & -- & -- & -- & -.0229 \\
\hline & -- & -- & -- & -- & -- & -- & -- & 0.000 \\
\hline \multirow[t]{2}{*}{ Constant } & 0.211 & 1.083 & 0.147 & 0.991 & 0.258 & 0.625 & -0.877 & -0.265 \\
\hline & 0.001 & 0 & 0.278 & 0 & 0.083 & 0.112 & 0 & 0 \\
\hline Parms & 5 & 5 & 5 & 5 & 5 & 5 & 5 & 6 \\
\hline RMSE & 0.508 & 0.55 & 0.508 & 0.529 & 0.588 & 0.424 & 0.504 & 0.544 \\
\hline R-sq & 0.414 & 0.233 & 0.356 & 0.260 & 0.308 & 0.552 & 0.358 & 0.320 \\
\hline $\operatorname{chi}^{2}$ & 3085.4 & 549.7 & 624.5 & 180.76 & 2163.7 & 759.05 & 959.6 & 5712.3 \\
\hline Prob $>$ chi 2 & 0.000 & 0.000 & 0.000 & 0.000 & 0.000 & 0.000 & 0.000 & 0.000 \\
\hline Mean VIF & 1.023 & 1.136 & 1.286 & 1.140 & 1.981 & 1.981 & 1,9651 & 1,184 \\
\hline DW- test & 1.957 & 1.698 & 1.947 & 1.993 & 1.386 & 2.087 & 1,160 & 1.897 \\
\hline J-B test & 0.000 & 0.000 & 0.000 & 0.000 & 0.000 & 0.000 & 0.000 & 0.000 \\
\hline $\mathrm{N}$ & 4369 & 2316 & 1128 & 944 & 1011 & 615 & 1718 & 12101 \\
\hline
\end{tabular}

Note: The significant coefficients are significant at the 0.01 level, Breusch-Pagan/Cook-Weisberg test for heteroskedasticity: Ho: Constant variance, $\mathrm{chi}^{2}(1)=$ Prob $>\mathrm{chi}^{2}=0.0000$ for all variables 
The results show that the complete SUR model with six independent variables accounts for around $32 \%$ of the variance in firm growth. Other variables, including managerial, contextual and macroeconomic, account for the remaining $78 \%$ of the variance. This is a relatively adequate level of explanatory power, given the sample size and the number of independent variables considered. The validity tests of the model including the F-statistic, Durbin-Watson test, variance inflation factor (VIF) and the Breusch-Pagan/Cook-Weisberg tests, and the Jarque-Bera (J-B) normality test confirm that the complete model is appropriate for hypothesis testing.

As mentioned previously, industry affiliation is found to explain some part of growth variation among firms. The results of the SUR models for each industry sector are provided in the next section.

\subsubsection{SUR Model for Each Industry}

In order to analyse how the impact of financial constraints on growth varies across sectors, the estimate equations for each industry (defined at the 1-digit level) were conducted separately. The results of the SUR models for each industry sectors are presented in Table 3, showing significant impact of age, size, and retained profit on growth for all industry sectors. These findings are similar to the results of the complete SUR model and are consistent with Hypotheses 2, 3, and 4. However, the explanatory power of the independent variables in terms of coefficients varies depending on each industry affiliation. Short-term debt also has a significant and positive effect on growth for all industry sectors except agriculture. The explanation is that the short-term debt ratio of the agricultural industry is very low compared with all other industries (see Table 1). Contrary to Hypothesis 1, firm age affects growth negatively. But the magnitude of the effect of age on firm growth in terms of the beta coefficient on average varies by industry affiliation. While the beta value is on average the highest for the retail trade sector, the health sector accounts for the lowest age beta. Similar industry effects can be observed with regard to the explanatory power of other independent variables on growth. While the health sector accounts for the highest beta coefficient for size, the agricultural sector represents the lowest effect of size on growth. Yet again, the metal industry presents the highest impact of retained profit on growth. Interestingly, the restaurant industry accounts for the lowest effect of the variable on growth.

\subsubsection{Firm Growth for Different Sectors}

The explanatory power of the models for across industries expressed in R square (R-sq) varies between $26 \%$ and $55 \%$. The agricultural sector has the highest and the restaurant sector the lowest explanatory power.

The complementary opposite effect between retained profit and short-term debt can be observed in the retail trade, consulting, metal, and construction sectors. The diagnostics tests of the model, including the F-statistic, Durbin-Watson test, VIF, the Breusch-Pagan/Cook-Weisberg tests, and the J-B normality test confirm the overall robustness of the model.

The general interpretation of the findings is that the ability to achieve a portion of growth is a function of all significant variables and also a function of industry affiliation. Indeed, the younger, larger, and profitable firms with more financial resources at their disposal have higher growth rates. However, high growth firms rely more on internal financial resources than external funding.

\section{Conclusions}

The paper has investigated two questions: How is firm growth associated with pattern of financing sources? Are internal or external sources linked differently to firm growth? In particular, the purpose of the analysis has been to shed some light on the impact of capital structure and sources of funding on firm growth. The study focused on a few variables to explain growth among Swedish micro firms. These variables were chosen on the basis of the literature review.

The access to broad, comprehensive databases at the firm level and the application of the SUR model has provided new empirical evidence on the impact of financing pattern on growth. To the author's knowledge, this is one of the first studies to consider the association between different financial sources and growth among micro firms in Sweden. The empirical results show that retained profit and short-term debt variables have a positive impact on growth. These variables increase as a firm gains higher growth rates. On the other hand, firm growth seems not to be associated with long-term debt. The findings also indicate that, in general, the growth rates of firms are more sensitive to internal sources, such as retained profit, than to short-term debt. This implies, consistent with agency cost theory, that firms with high growth rate are more likely to use internal sources than external ones. Moreover, firm growth is found to increase with the firm's size and decrease as the firm ages. This implies that larger and younger firms are more likely to generate internal finance and then achieve higher growth. The impact of funding sources on firm growth is not constant across industry sectors. Thus, industry affiliation has a certain impact on the relationship between independent and dependent variables. 


\section{References}

Aghion, P., Fally, T., \& Scarpetta, S. (2007). Credit constraints as a barrier to the entry and post-entry growth of firms. Economic Policy, 22, 731-790. http://dx.doi.org/10.1111/j.1468-0327.2007.00190.x

Almeida, H., \& Campello, M. (2007). Financial constraints, asset tangibility and corporate investment. Review of Financial Studies, 20, 1429-1460. http://dx.doi.org/10.1093/rfs/hhm019

Audretsch, D., \& Elston, J. (2002). Does firm size matter? Evidence on the impact of liquidity constraints on firm investment behaviour in Germany. International Journal of Industrial Organization, 20(1), 1-17. http://dx.doi.org/10.1016/S0167-7187(00)00072-2

Autio, E. (2005). Creative tension, the significance of Ben Oviatt's and Patricia McDougall's article 'Toward a theory of international new ventures'. Journal of International Business Studies, 36(1), 9-19. http://dx.doi.org/10.1057/palgrave.jibs.8400117

Barclay, M. J., Smith, C. W., \& Watts, R. L. (1995). The determinants of corporate leverage and dividend policies. Journal of Applied Corporate $\quad$ Finance, $\quad 7(4), \quad 4-19$. http://dx.doi.org/10.1111/j.1745-6622.1995.tb00259.x

Barton, S. L., Ned, C. H., \& Sundaram, S. (1989). An empirical test of stakeholder theory predictions of capital. Financial Management, 18(1), 36-44. http://dx.doi.org/10.2307/3665696

Becchetti, L., \& Trovato, G. (2002). The determinants of firm growth for small and medium sized firms: The role of the availability of external finance. Small Business Economics, 19(4), 291-306. http://dx.doi.org/10.1023/A:1019678429111

Beck, T., Demirgüc-Kunt, A., \& Maksimovic, V. (2005). Financial and legal constraints to growth: Does firm size matter? Journal of Finance, 60(1), 137-177. http://dx.doi.org/10.1111/j.1540-6261.2005.00727.x

Cassar, G., \& Holmes, S. (2003). Capital structure and financing of SMEs: Australian evidence. Accounting and Finance, 43, 123-147. http://dx.doi.org/10.1111/1467-629X.t01-1-00085

Castrogiovanni, G. J. (1996). Pre-startup planning and the survival of new small businesses: Theoretical linkages. Journal of Management, 22(6), 801-822. http://dx.doi.org/10.1177/014920639602200601

Childs, P. D., Mauer, D. C., \& Ott, S. H. (2005). Interactions of corporate financing and investment decisions: The effects of agency conflicts. Journal of Financial Economics, 76, 667-690. http://dx.doi.org/10.1016/j.jfineco.2004.06.012

Chittenden, F., Hall, G., \& Hutchinson, P. (1996). Small firm growth, access to capital markets and financial structure: Review of issues and an empirical investigation. Small Business Economics, 8(1), 59-67. http://dx.doi.org/10.1007/BF00391976

Das, S. (1995). Size, age and firm growth in an infant industry: The computer hardware industry in India. International Journal of Industrial Organization, $111-126$. http://dx.doi.org/10.1016/0167-7187(94)00453-9

Delmar, F. (1997). Measuring growth: methodological considerations and empirical results. In Donckels, R., \& Miettinen, A. (Eds.), Entrepreneurship and SME research: On its way to the next millennium. Aldershot, Ashgate.

Delmar, F., Davidsson, P., \& Gartner, W. B. (2003). Arriving at the high-growth firm. Journal of Business Venturing, 18(2), 189-216. http://dx.doi.org/10.1016/S0883-9026(02)00080-0

Elston, J. A. (1993). Firm ownership structure and investment theory and evidence from German panel data. Wissenschaftszentrum Berlin (WZB). Discussion paper no. FS IV 93.

Esperança, J. P., Gama, A. P. M., \& Gulamhussen, M. A. (2003). Corporate debt policy of small firms: An empirical (re)examination. Journal of Small Business and Enterprise Development, 10(1), 62-80. http://dx.doi.org/10.1108/14626000310461213

Evans, D. S. (1987). The relationship between firm growth, size and age: Estimates for 100 manufacturing industries. Journal of Industrial Economics, 35(4), 567-581. http://dx.doi.org/10.2307/2098588

Gilbert, B. A., McDougall, P. P., \& Audretsch, D. B. (2006). New venture growth: A review and extension. Journal of Management, 32(6), 926-950. http://dx.doi.org/10.1177/0149206306293860 
Hall, G., Hutchinson, P., \& Michaelas, N. (2004). Determinants of the capital structures of European SMEs. Journal of Business Finance \& Accounting, 31(5-6), 711-728. http://dx.doi.org/10.1111/j.0306-686X.2004.00554.x

Hart, P. E. (2000). Theories of firms' growth and the generation of jobs. Review of Industrial Organisation, 17(3), 229-48. http://dx.doi.org/10.1023/A:1007887626165

Hobdari, B., Derek, C. J., \& Mygind, N. (2009). Capital investment and determinants of financial constraints in Estonia. Economic Systems, 33(4), 344-359. http://dx.doi.org/10.1016/j.ecosys.2009.05.004

Hutchinson, R. W. (1995). The capital structure and investment decision of the small owner-managed firm: Some exploratory issues. Small Business Economics, 7(3), 231-129. http://dx.doi.org/10.1007/BF01135368

Jensen, M., \& Meckling, W. (1976). Theory of the firm: Managerial behavior, agency costs and ownership $\begin{array}{lllll}\text { structure. Journal of } & \text { Financial }\end{array}$ http://dx.doi.org/10.1016/0304-405X(76)90026-X

Jordan, J., Lowe, J., \& Taylor, P. (1998). Strategy and financial policy in UK small firms. Journal of Business Finance and Accounting, 25(1), 1-27. http://dx.doi.org/10.1111/1468-5957.00176

Jovanovic, B. (1982). Selection and the evolution of industry. Econometrica, 50(3), 649-70. http://dx.doi.org/10.2307/1912606

Katsikeas, C. S., \& Piercy, N. F. (1993). Long-term export stimuli and firm characteristics in a European LDC. Journal of International Marketing, 1(3), 23-47.

Kester, C. W. (1986). Capital and ownership structure: A comparison of United States and Japanese manufacturing corporations. Financial Management, 15, 5-16. http://dx.doi.org/10.2307/3665273

Kim, W. S., \& Sorensen. E. H. (1986). Evidence on the impact of the agency costs of debt on corporate debt policy. Journal of Financial and Quantitative Analysis, 21(2), 131-145. http://dx.doi.org/10.2307/2330733

McConnell, J. J., \& Servaes, H. (1995). Equity ownership and the two faces of debt. Journal of Financial Economics, 39, 131-157. http://dx.doi.org/10.1016/0304-405X(95)00824-X

Michaelas, N., Chittenden, F., \& Poutziouris, P. (1999). Financial policy and capital structure choice in UK SMEs: Empirical evidence from company panel data. Small Business Economics, 12(1), 113-130. http://dx.doi.org/10.1023/A:1008010724051

Müller, E., \& Zimmermann, V. (2008). The importance of equity finance for R\&D activity: Are there differences between young and old companies? ZEW Discussion Papers 06-14, Center for European Economic Research, Mannheim, Germany.

Myers, S. C. (1977). Determinants of corporate borrowing. Journal of Financial Economics, 5(2), 147-175. http://dx.doi.org/10.1016/0304-405X(77)90015-0

Myers, S. C., \& Majluf, N. S. (1984). Corporate financing and investment decisions when firms have information that investors do not have. Journal of Financial Economics, 13(2), 187-221. http://dx.doi.org/10.1016/0304-405X(84)90023-0

North, D., \& Smallbone, D. (1995). Employment generation and small business growth in different geographical environments. In Chittenden, F., Robertson, M., Marshall, I., \& London, I. (Eds.), Small firms: Partnership for growth (pp.100-115). London: Paul Chapman Publishing.

Oliveira, B., \& Fortunato, A. (2006). Firm growth and liquidity constraints: A dynamic analysis. Small Business Economics, 27(1), 139-56. http://dx.doi.org/10.1007/s11187-006-0006-y

Pagano, P., \& Schivardi, F. (2003). Firm size distribution and growth. Scandinavian Journal of Economics, 105(2), 255-274. http://dx.doi.org/10.1111/1467-9442.t01-1-00008

Philp, N. E. (1998). The export propensity of the very small enterprise (VSE). International Small Business Journal, 16(4), 79-93. http://dx.doi.org/10.1177/0266242698164005

Rajan, R., \& Zingales, L. (1995). What do we know about capital structure? Some evidence from international data. Journal of Finance, 50(5), 1421-1460. http://dx.doi.org/10.1111/j.1540-6261.1995.tb05184.x

Reid, G. C. (2003). Trajectories of small business financial structure. Small Business Economics, 20(4), 273-285. http://dx.doi.org/10.1023/A:1022915308274 
Roden, D., \& Lewellen, W. (1995). Corporate capital structure decisions: Evidence from leveraged buyouts. Financial Management, 14(1), 76-87. http://dx.doi.org/10.2307/3665536

Shrivastava, P., \& Grant, J. H. (1985). Empirically derived models of strategic decision-making processes. Strategic Management Journal, 6(2), 97-113. http://dx.doi.org/10.1002/smj.4250060202

Storey, D. J. (1994). Understanding the small business sector. London and Boston: International Thomson Business Press.

Stulz, R. (1990). Managerial discretion and optimal financial policies. Journal of Financial Economics, 26(1), 3-27. http://dx.doi.org/10.1016/0304-405X(90)90011-N

Titman, S., \& Wessels, R. (1988). The determinants of capital structure choice. Journal of Finance, 43(1), 1-19. http://dx.doi.org/10.2307/2328319

Variyam, J. N., \& Kraybill, D. S. (1992). Empirical evidence on determinants of firm growth. Economic Letters, 38(1), 31-36. http://dx.doi.org/10.1016/0165-1765(92)90157-T

Wiklund, J. (1998). Small firm growth and performance: Entrepreneurship and beyond. Academic Dissertation, Jönköping: Jönköping International Business School.

Yasuda, T. (2005). Firm growth, size, age and behavior in Japanese manufacturing. Small Business Economics, 24(1), 1-15. http://dx.doi.org/10.1007/s11187-005-7568-y 